\title{
Farm economic analyis of walnut production
}

\author{
Apáti, F. \\ University of Debrecen, Centre for Agricultural Sciences, Faculty of Applied Economics and Rural Development, \\ Institute of Business Economics
}

\begin{abstract}
Summary: In this present study the returning issues and profit conditions of domestic walnut production are investigated. Our objective is to determine the fact that under what conditions our walnut production may be competitive and maintained in an economic way regarding the present economic and market situations. Our analysis was carried out by a deterministic model based on a farm-level data gathering in production enterprises. The total investment cost of an up-to-date walnut orchard is up to 3000 thousands HUF per hectare and turning to productivity is expected within $8-10^{\text {th }}$ years. These orchards are able to produce a yield of 3 tons per hectare in the years of productivity in a normal year, thus in case of a medium-good selling prices a profit of 500 thousand HUF per hectare may be realized. As a result at the end of the whole lifetime of the orchard ( $30^{\text {th }}$ year) an internal rate of return (IRR) of 10 to $12 \%$ may be calculated and the return is expected in the $20^{\text {th }}$ to $22^{\text {nd }}$ year, which may be considered as a very late return. Taking the 20 to $25 \%$ probability of harmful whether phenomena (frost, drought) into consideration, it may be concluded that in good years a performance reaching a yield of 4 tons per hectare is necessary in the long-run in order to achieve the profitable and sustainable production in an economic way. This is managed to reach in only the most up-todate orchards.
\end{abstract}

Keywords: walnut, walnut production, economic analysis

\section{Introduction}

Fruit production has a highlighted role in the agriculture of Hungary, which is proved by the fact that it employs a significant number of workers, binds assets in billions of value, and accounts for 8 to $10 \%$ of the production value of plant production (Z. Kiss, 2003). Fruit production has a great significance in improving the life standard of the population in lagged behind areas having weaker natural conditions for production and in implementing rural development programs (Papp, 1999). The decline of the sector reflected in the continuous decline of quality and the technical and technological standard and even the state of productive stock deteriorated besides the decrease in quantity. In addition these negative processes new tendencies appeared during the past half decade, the use of marketable varieties, settling up-to-date, intensive orchards and technical-technological development started in Europe (Mihályka, 2004). Regarding all these the Hungarian vegetable and fruit industry does not approach its maximal performance ability at all (Lux, 2005).

The territory of walnut production in Hungary has been reflecting a continuous increase since the beginning of the 2000-ies. Besides the good market opportunities it is thanked to the reform of the Common Agricultural Policy in 2003, when the territory-based subsidy was introduced. Between 2004 and 2010, the territory of walnut production increased by 2000 hectares. According to the data of ÁMÖ (General Agricultural Report) Hungary had 5563 hectares walnut territories in 2010. This is more than it was in 2002 by 3700 hectares. Though walnut trees need 7 to 8 years while they turn to productivity, the harvested quantities increase yearly, regardless several years having unfavourable whether conditions $(2007,2010,2011)$. On the basis of the data of ÁMÖ, walnut was produced in 27,4 thousand farms in 2010. The major part of the farms cultivated less than one hectare. The ratio of farms operating walnut territories of more than 30 hectares was only $0,3 \%$ of the total farms, but they had the $31,1 \%$ of the walnut territory (Radóczné, 2012). The average farm size of the biggest walnut producers in the world is the following: it is 10 to 15 hectares in Chile, 6 to 8 hectares in France, 20 to 30 hectares in the USA (Hennicke, 2011a).

\section{Objective}

Our objective is to determine the fact that what cost and profit relations are typical to the production and under what condition an up-to-date walnut orchard may be profitable, which is handled in an excellent way and operated on a high technological standard. The orchard investment is a very long-term activity thus the profitability and the efficiency of the whole investment cannot be measured by economic analysing only a single year. The short-term analysis focusing on one year do not reflect the characteristic of the orchards that their settlement needs a huge one-time investment, and high inputs are necessary for their cultivation, revenue is hardly realized in the first years, the profitability ranges in a wide interval due to several risk factors, thus in our study even investment analysis on return for the whole life-time of the orchard was carried out. 


\section{Materials and methods}

In our present study the cost and profit relations of walnut orchards in traditionally cultivated system cultivated on a high standard, being in good conditions were examined. The parameters of the characterized orchard type are the following:

- natural, spherical crown shape,

- distance between rows is $10 \mathrm{~m}$, distance within a row is $8 \mathrm{~m}$ ( 125 trees per hectare)

- Alsószentiváni 117, Milotai 10 and Tiszacsészi 83 varieties constitute the major portion in the variety structure,

- the irrigation system is micro-irrigation (drip irrigation, sprinkler irrigation),

- the technology of harvesting is mechanical shaking,

- in good years the reachable yield level is 3 to 4 tons per hectare (90\% is of I. class, $10 \%$ is of II. class)

- product: hulled in-shell walnut without drying, selling right after harvesting (costs of drying, storage, selection and packaging do not arise.)

Such an orchard may be characterized by yields exceeding the national average, good product quality (size, ripeness), high inputs, production technology of good standard and strict technological discipline. It must be highlighted that these parameters reflect not the Hungarian average but the best orchards belonging to the upper third. The prices of the utilized inputs (materials, labour, mechanical work) and the prime cost reflect a price standard in 2012-2013 years. The price of materials lacks the VAT, while the wages of labour is considered altogether with benefits. The time wage was 600 HUF per hour, and it was calculated to every labour hour regardless the fact that whether paid or unpaid family labour worked. The selling prices are represented by a longer-term ( 3 to 5 years) average. Data gathering basing the analysis happened in production enterprises.

In case of the examined model (orchard) good production standard and strict technological discipline were set, thus the calculation refers not to the national average but to up-todate firms producing on good standard, which take up of 20 to $30 \%$ of the 5000 hectares walnut orchard.

The utilized analysing methods are cost-benefit analysis and investment analysis on return. In the latter case the dynamic methods were chosen as they give a more valid and precise results from the professional aspects. They differ from static methods in the fact that they count with the time value of the money (Illés, 2002). There are several indicators for dynamic investment analysis, from which NPV (Net Present Value), DPP (Discounted Payback Period), IRR (Internal Rate of Return, return on capital) are calculated (Flock, 2000; Brealey, 2006). The return on capital of alternative investment is reflected by the calculative interest rate, which value is $7 \%$, being the interest need of the investment capital.

\section{Results}

\section{Investment costs}

The establishment cost of an orchard (Table 1) may be classified into five major cultivation phases: site and soil preparation, establishing the support equipment, planting, building the irrigation system and other phases. An up-to-date but traditionally cultivated walnut orchard does not require the support equipment, but the water friendly drop irrigation takes part of the technology. Two determining costs of the establishment costs are the graft and planting as well as the cost of settling the irrigation system. Though due to the wide spacing only 125 grafts are necessary in one hectare, but the price of a planting material of good quality is about 2500 HUF, which results in altogether a high cost. Walnut is one of the most water-intensive fruit type, it may realize serious yield decrease in extremely drought years, thus establishing the irrigation system is necessary by all means.

Table 1: The investment cost of the characterized walnut orchard

\begin{tabular}{|l|c|}
\hline \multicolumn{1}{|c|}{ Denomination } & Cost (thousand HUF/ha) \\
\hline Site and soil preparation & 390 \\
\hline Establishing the support equipment & 0 \\
\hline Graft and planting & 400 \\
\hline Establishing irrigation system & 560 \\
\hline Other & 250 \\
\hline Total establishing costs & 1600 \\
\hline $\begin{array}{l}\text { Cultivation cost in the period of turn- } \\
\text { ing to productivity (9 years) }\end{array}$ & 1350 \\
\hline Total investment cost & 2950 \\
\hline $\begin{array}{l}\text { Revenue in the period of turning to } \\
\text { productivity }\end{array}$ & 420 \\
\hline Clear investment cost & 2530 \\
\hline $\begin{array}{l}\text { Annual depreciation cost in the period } \\
\text { of productivity }\end{array}$ & 82 \\
\hline
\end{tabular}

Source: own calculation

On the basis of data in Table 1, the establishment of walnut orchard needs 1,5 to 2,0 million HUF per hectare. The cultivation cost of the first 9 years (the period of turning to productivity) is similar to this amount, thus altogether a total investment cost of 3 million HUF may be calculated. During the first 5 to 6 years, yields cannot be considered, but after this period, smaller amount of yields may be harvested (altogether 1,0 to 1,5 tons per hectare in the period of turning to productivity), which may be sold and revenue of 500 thousand HUF may be realized. The orchard reaches the period of total yields in its 15 to 20 years of age. As a result the clear investment cost is 2,5 million HUF per hectare, which may be depreciated to 30 years because of the lifetime of orchard reaching the 40 years. 


\section{Input and production cost in productive period}

The per kilogram prime cost in case of walnut, just like in case of any other fruit ranges to a relevant degree depending on the given year, as the per hectare production costs do not show big differences in a set basic technology, but the annual yield may range within a wide interval ( 0,0 to 4,0 tons per hectare). Because of the reasons above mentioned, the cost and profit calculations were carried out to three different year versions, where different yield levels were supposed.

Table 2: The production cost of a walnut orchard in cultivation phases cultivated on a good standard in a whole year in case of different year versions

\begin{tabular}{|c|c|c|c|c|c|c|}
\hline \multirow[b]{3}{*}{ Cultivation phases } & \multicolumn{6}{|c|}{ Year versions } \\
\hline & \multicolumn{2}{|c|}{ Yield: 3 t/ha } & \multicolumn{2}{|c|}{ Yield: 2 t/ha } & \multicolumn{2}{|c|}{ Yield: 1 t/ha } \\
\hline & $\begin{array}{c}\text { Cost } \\
\text { (thou- } \\
\text { sand } \\
\text { HUF/ } \\
\text { ha) } \\
\end{array}$ & $\begin{array}{c}\text { Cost } \\
\text { (HUF/ } \\
\text { kg) }\end{array}$ & $\begin{array}{c}\text { Cost } \\
\text { thou- } \\
\text { sand } \\
\text { HUF/ } \\
\text { ha) }\end{array}$ & $\begin{array}{c}\text { Cost } \\
\text { (HUF/ } \\
\text { kg) }\end{array}$ & $\begin{array}{c}\text { Cost } \\
\text { thou- } \\
\text { sand } \\
\text { HUF/ } \\
\text { ha) } \\
\end{array}$ & $\begin{array}{c}\text { Cost } \\
\text { HUF/ } \\
\text { kg) }\end{array}$ \\
\hline Pruning & 41 & 13,7 & 41 & 20,5 & 41 & 41,0 \\
\hline $\begin{array}{l}\text { Soil and spacing } \\
\text { cultivation }\end{array}$ & 28 & 9,3 & 28 & 14,0 & 28 & 28,0 \\
\hline Fertilizing & 55 & 18,3 & 42 & 21,0 & 35 & 35,0 \\
\hline Plant protection & 92 & 30,7 & 85 & 42,5 & 78 & 78,0 \\
\hline $\begin{array}{l}\text { Irrigation (annual } \\
\text { cost) }\end{array}$ & 43 & 14,3 & 43 & 21,5 & 43 & 43,0 \\
\hline Harvesting & 211 & 70,3 & 195 & 97,5 & 175 & 175,0 \\
\hline $\begin{array}{l}\text { Other work and } \\
\text { cost }\end{array}$ & 25 & 8,3 & 25 & 12,5 & 25 & 25,0 \\
\hline $\begin{array}{l}\text { Depreciation of } \\
\text { orchard }\end{array}$ & 82 & 27,3 & 82 & 41,0 & 82 & 82,0 \\
\hline Total direct cost* & 577 & 192,3 & 541 & 270,5 & 507 & 507,0 \\
\hline Overhead cost & 100 & 33,3 & 100 & 50,0 & 100 & 100,0 \\
\hline $\begin{array}{l}\text { Total production } \\
\text { cost }\end{array}$ & 677 & 225,7 & 641 & 320,5 & 607 & 607,0 \\
\hline $\begin{array}{l}\text { From which: } \\
\text { operation cost }\end{array}$ & 595 & 198,3 & 559 & 279,5 & 525 & 525,0 \\
\hline
\end{tabular}

Source: own data gathering and calculation

* Note: The production costs refer to in-shell walnut without post-harvest costs (drying, storage, selection, packaging, transportation, selling).

When examining production costs it may be concluded that the yield (3,0 tons per hectare) of a normal year may be realised by 700 thousand HUF per hectare cost. This includes even the overhead costs, which value may range within a wide interval depending on the size of the firm, the production structure, organizational structure, etc. (Table 2). The prime cost per kilogram of walnut is determined by the yield level and the reachable labour performance of harvesting. Other cultivation phases or factors do not cause unexpected changes and their ratio is not too high. It is clear that by the significant decrease (30 to $70 \%$ ) of yields production cost decline only by 10 to $20 \%$, thus in case of walnut the reached yield has an extremely great significance from the aspects of the realized prime cost and profit. By all these the production cost of one $\mathrm{kg}$ in-shell walnut without husk, being not dried ranges from 225 and 600 HUF per kilogram.

\section{Yield, production value, profit and profitability in the period of productivity}

Table 3 summarizes the calculation of production value and profit relating to the three year versions. Selling prices for in-shell walnut showed a relatively favourable tendency during the past years: there have been average prices of 350 to 400 HUF per kilogram since 2010, while the selling price ranged from 280 to 350 HUF per kilogram during the years before 2010. It is a positive tendency as well, that there have not been any selling problems during the last years, mainly a demand market appeared toward the in-shell walnut. These prices relate to I. class goods (price of products of II. class is lower by 30 to $40 \%$ ), thus the realized average price significantly depends on the quality as well.

Table 3: Revenue, profit and profitability of walnut orchard cultivated on a good standard in a whole year in case of different year versions

\begin{tabular}{|c|c|c|c|c|}
\hline \multirow[b]{2}{*}{ Denomination } & \multirow[b]{2}{*}{ Unit } & \multicolumn{3}{|c|}{ Year versions } \\
\hline & & $\begin{array}{l}\text { Yield: } \\
3 \text { t/ha }\end{array}$ & $\begin{array}{l}\text { Yield: } \\
2 \text { t/ha }\end{array}$ & $\begin{array}{l}\text { Yield: } \\
1 \text { t/ha }\end{array}$ \\
\hline Total yield* & $\mathrm{t} / \mathrm{ha}$ & 3,0 & 2,0 & 1,0 \\
\hline $\begin{array}{l}\text { Average selling } \\
\text { price }\end{array}$ & HUF/kg & 350,0 & 350,0 & 350,0 \\
\hline Total revenue & $\begin{array}{l}\text { thousand } \\
\text { HUF/ha }\end{array}$ & 1050,0 & 700,0 & 350,0 \\
\hline $\begin{array}{l}\text { Direct production } \\
\text { cost }\end{array}$ & $\begin{array}{l}\text { thousand } \\
\text { HUF/ha }\end{array}$ & 577,0 & 541,0 & 507,0 \\
\hline Contribution & $\begin{array}{l}\text { thousand } \\
\text { HUF/ha }\end{array}$ & 473,0 & 159,0 & $-157,0$ \\
\hline Overhead cost & $\begin{array}{l}\text { thousand } \\
\text { HUF/ha }\end{array}$ & 100,0 & 100,0 & 100,0 \\
\hline Net profit $* *$ & $\begin{array}{l}\text { thousand } \\
\text { HUF/ha }\end{array}$ & 373,0 & 59,0 & $-257,0$ \\
\hline Cash flow & $\begin{array}{l}\text { thousand } \\
\text { HUF/ha }\end{array}$ & 455,0 & 141,0 & $-175,0$ \\
\hline Profit to cost ratio & $\%$ & 55,1 & 9,2 & $-42,3$ \\
\hline
\end{tabular}

Source: own data gathering and calculation

$* 90 \%$ of the yield is of I. class, $10 \%$ is of II. class

** profit before taxes

The production value and profitability of the year version in Table 3 may be evaluated as follows. In a good year in case of a yield of 3,0 tons per hectare even a per hectare revenue of more than 1,0 million HUF may be reached by walnut. Thus a profit of 400 thousand HUF per hectare and a profit to cost ratio of 50 to $60 \%$ may be realized, which indicators may be considered as acceptable all in all. It may be concluded that a yield of a worse year (2,0 tons per hectare) can provide only a modest profit; furthermore, depending on the realized average selling price a yield level of between 1,5 to 2,0 tons per hectare is the breakeven point, which can be considered as the turning point of the profitability in the given year. One of the favourable farm economic characteristics of the walnut is that in case of total yield damage, it can be cultivated with a minimal loss, as the value of the production technological inputs does not exceed the 200 to 250 thousand HUF per hectare. 


\section{Returning of the investment during the lifetime of the orchard}

Only the most important results are summarized here due to space limitations. When calculating the investment return indicators a calculative interest rate of $7 \%$ formed the basis. According to our results without any investment subsidies (in case of an establishment from own source of 100\%) and regardless direct production subsidies, the payback period of the investment is 20 to 25 years in good cases, while it is 25 to 30 years or more in case of a worse situation. Because of the very long lifetime the time value of the money extremely declines in the second part of the period of productivity, thus the NPV is 1,0 to 1,5 million HUF per hectare in a realistic case at the end of the 30 to 40-year-long lifetime, the return on capital (IRR) is 8 to $10 \%$ (by which it lags behind the more intensive fruit species). Regarding investment and direct production subsidies the payback period shorten by 5 to 10 years, while the value of NPV become 2,2 to 2,8 million HUF per hectare and the IRR increase to 12 to $15 \%$.

\section{Conclusions}

On the basis of the results the major farm economic advantages and disadvantages of the walnut are summarized as follows.

The major farm economic advantages of walnut are:

- low capital need for the establishment at the beginning,

- low input need in the years of productivity,

- relatively low production risk (frost, danger of ice damages, drought, discontinuous yielding, etc.) comparing to other fruit species,

- the relatively low profit may result in an acceptable and good profit to cost ratio because of low production costs,

- in case of total yield damage, the realized loss is low,

- good market position, favourable selling opportunities.

The major farm economic disadvantages of walnut are:

- slow turning to productivity,

- late return (the payback period is 25 to 30 years without subsidies),

- rather low contribution, net profit, NPV and return on capital (IRR) comparing to other fruit species.

These farm economic features reflect that comparing to fruit species, walnut is a more extensive fruit species of a relatively low capital and input need, having a small production risk, which is able to reach a favourable profitability due to the low production costs (in case of good price of cereals, corn may reach similar value). The more intensive fruit species (intensive apple, semi-intensive apricot and sour cherry) realize multiple profit in a hectare than walnut, (thus walnut has not a perspective in firms organized for intensive cultivation), but walnut compete with them with respect to profit to cost ratio and its production risk is not high, at the same time its payback period is endlessly long. The above mentioned characteristics of walnut explain the fact that it shows a perspective for many small enterprises of poor capital and being organized for only extensive cultivation as besides its low input need its profit to cost ratio may be favourable, especially regarding subsidies. These favourable characteristics are similar in large enterprises as well and it is a positive fact that the production may be well mechanized.

In order to maintain and improve our competitiveness the starting point should be the fact that competitive means that solvent consumer demand exists towards the products, which can be sold in markets and the production is profitable. In our opinion, as a result of domestic and international development tendencies, only walnut orchards are expected to be competitive in the long-run, which are able to reach a yield of 3,0 to 4,0 tons per hectare in almost every year.

\section{Acknowledgement}

This research was supported by the European Union and the State of Hungary, co-financed by the European Social Fund in the framework of TÁMOP-4.2.4.A/ 2-11/1-20120001 'National Excellence Program'. The identification of the application is: A2-MZPD-13-0358

\section{References}

Brealey, R. A., Myers, S. C., Allen, F. (2006): Corporate Finance. Eight Edition, McGraw-Hill, 84-143., 244-272.

Flock, C. (2000): Betriebszweigabrechnung in der Landwirtschaft. Verlag Pflug und Feder. Sankt Augustin, 11-158.

Hennicke, L. (2011a): Chile. Tree Nuts Annual. Almond and Walnut Annual. GAIN Report. USDA Foreign Agricultural Service. http://static.globaltrade.net/files/pdf/ 20111012233854373.pdf

Illés M. (2002): A beruházások gazdaságossága. [In: Vezetői gazdaságtan.] Szerk.: Illés M. Kossuth Kiadó 115-162.

Lux R. (2005): A kertészet fejlesztési lehetőségei. Stratégiai munkaanyag, Fruitveb Magyar Zöldség-Gyümölcs Szakmaközi Szervezet Budapest

Mihályka L. (2004): Miért szorulunk almabehozatalra? Kertészet és Szőlészet. 4: 14.

Papp J. (1999): Az EU-összehasonlításban versenyképes kertészeti ágazatok fejlesztési koncepciójának alapjai. [In.: Versenyképes kertészeti ágazatok fejlesztési koncepciójának alapjai] - Stratégiai kutatások a Magyar Tudományos akadémián. (Szerk.: Papp J.) Agroinform Kiadó. Budapest, 8-14.

Radóczné K. T. (2012): Egyes perspektivikus gyümölcsfajok piaci helyzete. Agrárgazdasági Tanulmányok. Agrárgazdasági Kutatóintézet. Budapest, 7-18.

Z. Kiss, L. (2003): A gyümölcstermesztés feltételrendszere. [In.: A gyümölcs-termesztés, -tárolás, -értékesítés szervezése és ökonómiája.] (Szerk.: Z. Kiss). Mezőgazda Kiadó. Budapest, 13. 